\title{
SOIL SEED BANK AS A BIOINDICATOR TO IDENTIFY INVASIVE SPECIES
}

\author{
Ariane Cristine Araújo Silva1; Sebastião Venâncio Martins²; Diego Balestrin* \\ ${ }^{1}$ Universidade Federal de Viçosa, Departamento de Engenharia Florestal, Viçosa, Minas Gerais, Brasil - e-mail \\ ariane.florestal@yahoo.com.br; venancioufv@gmail.com; *diego.balest@gmail.com \\ Received for publication: 07/04/2020 - Accepted for publications: 24/10/2020
}

\begin{abstract}
Resumo
Banco de sementes do solo como bioindicador de espécies invasoras. Este estudo objetivou caracterizar o banco de sementes do solo de uma área dominada por Leucaena leucocephala, aqui denominada "Povoamento de Leucaena" (PL) e uma área de floresta nativa do Parque Estadual do Rio Doce (PERD), ambas sofrendo influência da área urbana do município de Ipatinga, MG. Foram instaladas 30 unidades amostrais (UA) com dimensões de 25,0 x 25,0 x 5,0 cm em cada uma das áreas de estudo, sendo coletado e avaliado o banco de semente das áreas. As plântulas emergentes foram contadas e identificadas, sendo as avaliações realizadas semanalmente durante o período de seis meses. A densidade média de sementes germinadas foi de 716,2 sementes $/ \mathrm{m}^{2}$ no PL e 86,4 sementes $/ \mathrm{m}^{2}$ na área do PERD. Além disso, foram identificadas 39 espécies na área do PL, sendo destas $41 \%$ exóticas, enquanto que na área do PERD foram identificadas 32 espécies e destas $25 \%$ exóticas. As espécies arbóreas exóticas que se destacaram em número de indivíduos foram a Muntingia calabura e L. leucocephala, representando $82,57 \%$ e $5,88 \%$ do total de indivíduos encontrados, respectivamente. Diante disso, ambos os ambientes estão sob forte pressão ambiental, sendo necessário o controle das espécies exóticas existentes, além de ações de enriquecimento com plantio de espécies de diversidade para acelerar o processo de restauração na área do PL.
\end{abstract}

Palavras-chave: Sementes, espécie exótica e regeneração natural

\begin{abstract}
This study aimed to characterize the soil seed bank in an area dominated by Leucaena leucocephala, here called "Povoamento de Leucaena" (PL) and an area of native forest in the Parque Estadual do Rio Doce (PERD), both of which are affected by the city of Ipatinga, MG. Thirty sample units (SU) with dimensions of $25.0 \times 25.0 \mathrm{x}$ $5.0 \mathrm{~cm}$ were installed in each of the study areas and the seed bank of the areas was collected and evaluated. The emerging seedlings were counted and identified; the evaluations were carried out weekly during the six-month period. The average density of germinated seeds was 716.2 seeds $/ \mathrm{m}^{2}$ in the PL and $86.4 \mathrm{seeds} / \mathrm{m}^{2}$ in the PERD area. In addition, 39 species were identified in the PL area (41\% exotic), while in the PERD area 32 species were identified ( $25 \%$ exotic). The exotic tree species that stood out in number of individuals were Muntingia calabura and L. leucocephala, representing $82.57 \%$ and $5.88 \%$, respectively of the total individuals found. Therefore, both environments are under strong environmental pressure, requiring the control of existing exotic species, as well as enrichment actions with the planting of species of diversity to accelerate the restoration process in the PL area.

Keywords: Seeds, exotic species and natural regeneration
\end{abstract}

\section{INTRODUCTION}

The seeds found in the soil seed bank constitute the reserve of viable and not readily germinatable seeds which are on the surface or inside the soil (MARTINS, 2009). The tropical forest seed bank is involved in at least four processes at population and community levels: the establishment of populations, the maintenance of species diversity, the establishment of ecological groups and the restoration of species richness during forest regeneration after natural or man-made disturbances (MARTINI and SANTOS, 2007). It is important in the natural colonization of disturbed areas, as it initiates the successional process (NETO et al., 2017; OLIVEIRA et al., 2018; BALESTRIN et al., 2019), as well as being one of the main bioindicators of ecosystem restoration (MARTINS, 2013).

In this sense, the importance of the seed bank for regeneration in tropical forests is related to the establishment of ecological groups, time and resources available to carry out restoration actions and knowledge of the resilience of different environments, thus being able to identify potential negative agents to the succession process and to manage the area in order to mitigate such effects (BALESTRIN et al., 2019). Therefore, certain plant species are highly aggressive, maintaining viable populations in the area's seed bank for decades, and may also inhibit the natural succession progress in these areas (CORREIA AND MARTINS, 2015).

In Brazil, in addition to problems faced with the invasion of Acacia mangium Willd., Pinus taeda L., Urochloa spp., among other species, Leucaena leucocephala has been identified as an inhibitor of succession in altered environments due to rapid colonization, high production, and seed dispersal and permanence in the seed bank (LIMA et al., 2020). In this sense, evaluating and monitoring seed banks are potential tools for management 
and decision making in projects for recovering degraded areas, assisting in defining restoration techniques consistent with the reality of each area, and especially in areas colonized by exotic and invasive species (CALEGARI et al., 2013).

In view of this, this study aimed to evaluate the dispersion of species with invasive potential in different environments through characterizing the soil seed bank found on the banks of Ribeirão Ipanema (colonized by $L$. leucocephala) and an area located in the Parque Estadual do Rio Doce, both located in the municipality of IpatingaMG, Brazil.

\section{MATERIAL AND METHODS}

\section{Study areas}

Area A: Area colonized by Leucaena leucocephala - Leucaena stand (PL).

Part of the study was carried out in a stretch of Ribeirão Ipanema, located in the city of Ipatinga, MG. This stream flows into the Rio Doce, with the region being inserted in the middle Rio Doce basin. The area is located in the Atlantic Forest domain, where small forest fragments are still found with a high level of edge effect, several of which are colonized by invasive species such as L. leucocephala and exotic grasses (mainly Urochloa spp). The region's climate is Aw type according to the Köppen classification (1948), characterizing a humid tropical savanna climate, megathermic.

The total area evaluated corresponds to approximately $2.5 \mathrm{ha}$, and the vegetation cover of this patch is characterized by a domain of young and adult $L$. leucocephala individuals (Figure 1). Due to the fact that the area in question is located in the urban perimeter of the municipality, it suffers direct anthropic influence through constant human access from the surrounding community (leisure).

Area B: Area inserted in the Parque Estadual do Rio Doce (PERD).

The Parque Estadual do Rio Doce (PERD) is more than 36,000 ha, and is currently the largest Submontane Semideciduous Seasonal Forest area in the state of Minas Gerais, according to data from the Instituto Estadual de Florestas $(I E F)$. It is located in the Vale do Aço region, and covers part of the municipalities of Marlieria, Dionísio and Timóteo, being limited by the Rio Doce to the east and the Rio Piracicaba to the north. Its forest formations are part of the Atlantic Forest biome and constitute a mosaic of plant types which are differentiated by the seral stage in which they are found and also due to environmental factors, such as soil fertility and water availability (SILVA et al., 2001).

The climatic classification is the same (Aw) because it is located approximately $4.3 \mathrm{~km}$ away from area A (PL). The vegetation cover can be considered a secondary forest with medium to advanced stage of succession, delimited (opposite bank of rivers) by the urban area of Ipatinga and also by eucalyptus plantations (Figure 1). In addition, the studied area is influenced by the Rio Doce because it is located close to its banks.

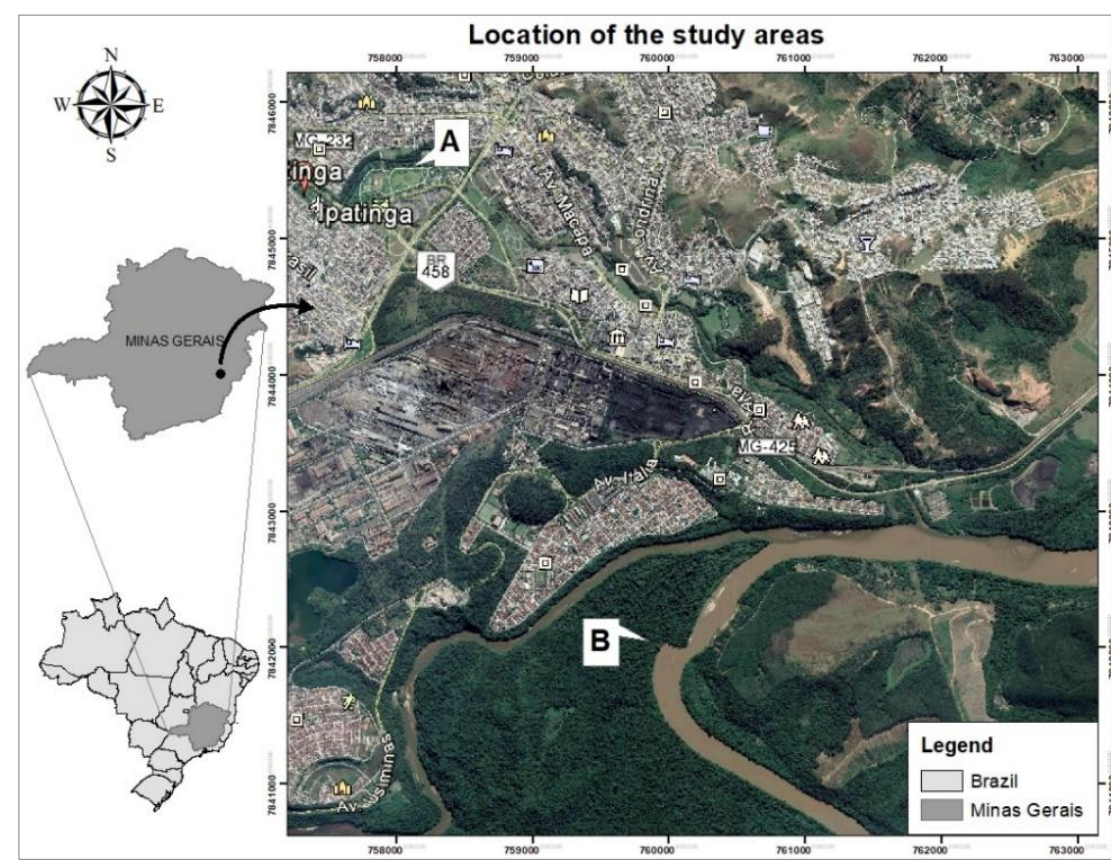

Figure 1 - Studied areas = A: Leucena stand in Ribeirão Ipanema; and B: section of the Parque Estadual do Rio Doce. 
Figura 1 - Áreas estudadas = A: Povoamento de Leucena no Ribeirão Ipanema e B: trecho do Parque Estadual do Rio Doce.

Fonte: Google Earth, 2017.

\section{Collection and evaluation methodology of the seed bank}

The demarcated area for the seed bank collection was $30 \times 30 \mathrm{~m}$ in each of the study areas, with 30 random sample units (SU's) of dimensions 25.0 × 25.0 × $5.0 \mathrm{~cm}$ being installed. Freshly fallen branches and leaves were excluded from the sampling, leaving only the litter in the final decomposition stage.

The removal of the topsoil at $5 \mathrm{~cm}$ depth was carried out in August with a gardening shovel, with the topsoil removed in each SU. The collected material was stored in black plastic bags, duly identified and the samples were transferred to the shade house of the nursery of the Universidade Federal de Viçosa/UFV (coverage with $50 \%$ shading), being placed in plastic trays under daily irrigation by sprinkler.

Next, eight $0.3 \mathrm{~cm}$ diameter perforations were made at the base of all trays in order to provide better water drainage. The trays were placed on a bench in the shade house at random and spaced $10 \mathrm{~cm}$ apart from each other, receiving uniform light and being isolated from external contamination. For greater security, five containers with sterile sand were distributed on the tables in order to detect possible contamination with seeds from outside areas.

The emerging seedlings were counted and identified, and the evaluations were carried out weekly during the six-month period. After identification, the seedlings were removed from the trays in order to have better control of the process and then classified into: woody, arboreal, herbaceous or climbing plants, and the number of individuals for each species; in addition, density and frequency were also calculated.

The species were identified according to the Angiosperm Phylogeny Group - APG IV (2016) and classified into succession categories, according to Gandolfi et al. (1995): pioneers, early secondary, late secondary, climax and no characterization. In addition, the species were classified according to the life form into: arboreal, shrub, herbaceous and vines, and regarding their origin: native or exotic.

\section{RESULTS}

The average density of germinated seeds per tray was 716.26 seeds $/ \mathrm{m}^{2}$ in the riparian area colonized by L. leucocephala (PL) and 86.4 seeds $/ \mathrm{m}^{2}$ in the PERD area. In addition, 39 species were found in the PL area and 32 species in the PERD area. Furthermore, 18 botanical families were found in each of the evaluated stands (Table $1)$.

Table 1 - Total germinated species in the seed bank of the studied areas (PL and PERD), located in Ipatinga, $\mathrm{MG} /$ Brazil, and respective life forms.

Tabela 1 - Total de espécies germinadas no banco de sementes das áreas estudadas (PL e PERD), localizadas em Ipatinga, MG/Brasil e respectivas formas de vida.

\begin{tabular}{|c|c|c|c|c|c|}
\hline \multirow{2}{*}{ FAMÍLIA/ESPÉCIE } & \multirow{2}{*}{ FV } & \multirow{2}{*}{ OR } & \multirow{2}{*}{ CS } & \multicolumn{2}{|c|}{$\mathbf{N}^{\circ}$ DE INDIVÍDUOS } \\
\hline & & & & PERD & PL \\
\hline \multicolumn{6}{|l|}{ AMARANTHACEAE } \\
\hline Alternanthera tenella Colla & Sub_B & $\mathrm{N}$ & PI & 10 & 0 \\
\hline Amaranthus hybridus L. & $\mathrm{E}$ & EX & PI & 0 & 2 \\
\hline Amaranthus spinosus L. & $\mathrm{E}$ & EX & PI & 0 & 2 \\
\hline $\begin{array}{l}\text { Dysphania ambrosioides (L.) Mosyakin \& Clemants } \\
\text { ASTERACEAE }\end{array}$ & Sub_B & $\mathrm{EX}$ & PI & 0 & 1 \\
\hline Ageratum conyzoides $\mathrm{L}$. & Sub_B & $\mathrm{N}$ & PI & 1 & 0 \\
\hline Baccharis crispa Spreng. & Sub_B & $\mathrm{N}$ & PI & 1 & 0 \\
\hline Blainvillea acmella (L.) Philipson & $\mathrm{E}^{-}$ & $\mathrm{N}$ & PI & 0 & 1 \\
\hline Centratherum punctatum Cass. & Sub_B & $\mathrm{N}$ & PI & 2 & 0 \\
\hline Conyza bonariensis (L.) Cronquist & Sub_B & $\mathrm{N}$ & PI & 0 & 4 \\
\hline Erechtites hieracifolius (L.) Raf. Ex DC. & $\mathrm{E}$ & $\mathrm{N}$ & PI & 0 & 1 \\
\hline Galinsoga parviflora Cav. & $\mathrm{E}$ & $\mathrm{N}$ & PI & 0 & 2 \\
\hline Gnaphalium spicatum Will. & $\mathrm{E}$ & $\mathrm{N}$ & SI & 2 & 0 \\
\hline Piptocarpha macropoda (DC.) Baker & A & $\mathrm{N}$ & PI & 2 & 5 \\
\hline Pterocaulon virgatum (L.) DC. & $\mathrm{E}$ & $\mathrm{N}$ & PI & 7 & 8 \\
\hline Senecio brasiliensis (Spreng.) Less. & Sub_B & $\mathrm{N}$ & PI & 6 & 1 \\
\hline Sigesbeckia orientalis L. & $\mathrm{E}$ & $\mathrm{N}$ & SI & 2 & 35 \\
\hline Spilanthes acmella (L.) Murray & $\mathrm{E}$ & $\mathrm{N}$ & PI & 1 & 1 \\
\hline Vernonanthura polyanthes (Sprengel) Vega \& Dematteis & $\mathrm{B}$ & $\mathrm{N}$ & PI & 0 & 2 \\
\hline Xanthium strumarium L. & $\mathrm{E}$ & $\mathrm{N}$ & PI & 0 & 1 \\
\hline
\end{tabular}




\begin{tabular}{|c|c|c|c|c|c|}
\hline \multicolumn{6}{|l|}{ BIGNONIACEAE } \\
\hline Spathodea campanulata P. Beauv. & A & EX & $\mathrm{SC}$ & 1 & 0 \\
\hline $\begin{array}{l}\text { Tabebuia sp. } \\
\text { CLEOMACEAE }\end{array}$ & A & $\mathrm{N}$ & $\mathrm{SC}$ & 3 & 0 \\
\hline $\begin{array}{l}\text { Tarenaya aculeata }(\text { L.) Soares Neto \& Roalson } \\
\text { CONVOLVULACEAE }\end{array}$ & $\mathrm{E}$ & $\mathrm{N}$ & PI & 0 & 2 \\
\hline $\begin{array}{l}\text { Ipomoea hederifolia } \mathrm{L} . \\
\text { CUCURBITACEAE }\end{array}$ & $\mathrm{T}$ & $\mathrm{N}$ & $\mathrm{SC}$ & 0 & 2 \\
\hline $\begin{array}{l}\text { Cayaponia trilobata (Cogn.) Cogn. } \\
\text { CYPERACEAE }\end{array}$ & $\mathrm{T}$ & $\mathrm{N}$ & $\mathrm{SC}$ & 1 & 0 \\
\hline $\begin{array}{l}\text { Cyperus iria } \mathrm{L} . \\
\text { EUPHORBIACEAE }\end{array}$ & $\mathrm{E}$ & $\mathrm{N}$ & PI & 35 & 9 \\
\hline Croton urucurana Baill. & A & $\mathrm{N}$ & PI & 4 & 0 \\
\hline $\begin{array}{l}\text { Ricinus communis (L.) Müll.Arg. } \\
\text { LAMIACEAE }\end{array}$ & $\mathrm{B}$ & EX & PI & 0 & 3 \\
\hline $\begin{array}{l}\text { Leonotis nepetifolia (L.) R. Br. } \\
\text { FABACEAE }\end{array}$ & $\mathrm{E}$ & EX & PI & 0 & 1 \\
\hline Aeschynomene rudis Benth. & $\mathrm{E}$ & $\mathrm{N}$ & PI & 0 & 2 \\
\hline Indigofera hirsuta $\mathrm{L}$. & $\mathrm{E}$ & $\mathrm{N}$ & PI & 2 & 0 \\
\hline Senegalia tenuifolia (L.) Britton \& Rose & $\mathrm{B}$ & $\mathrm{N}$ & PI & 1 & 0 \\
\hline $\begin{array}{l}\text { Leucaena leucocephala (Lam.) de Wit. } \\
\text { MALVACEAE }\end{array}$ & $\mathrm{B}$ & EX & PI & 2 & 79 \\
\hline Anoda cristata (L.) Schltdl. & $\mathrm{E}$ & EX & PI & 0 & 2 \\
\hline Sida cordifolia $\mathrm{L}$. & $\mathrm{E}$ & $\mathrm{N}$ & PI & 0 & 6 \\
\hline Sida spinosa $\mathrm{L}$. & Sub_B & $\mathrm{N}$ & PI & 4 & 0 \\
\hline $\begin{array}{l}\text { Theobroma cacao L. } \\
\text { MELASTOMATACEAE }\end{array}$ & A & $\mathrm{N}$ & ST & 4 & 0 \\
\hline $\begin{array}{l}\text { Leandra niangaeformis Cogn. } \\
\text { MORACEAE }\end{array}$ & $\mathrm{B}$ & $\mathrm{N}$ & PI & 14 & 0 \\
\hline $\begin{array}{l}\text { Brosimum guianense (Aubl.) Huber } \\
\text { MUNTINGIACEAE }\end{array}$ & $\mathrm{B}$ & $\mathrm{N}$ & SI & 1 & 0 \\
\hline $\begin{array}{l}\text { Muntingia calabura } \mathrm{L} \text {. } \\
\text { OXALIDACEAE }\end{array}$ & A & EX & PI & 20 & 1109 \\
\hline Oxalis corniculata $\mathrm{L}$. & $\mathrm{E}$ & EX & PI & 6 & 3 \\
\hline $\begin{array}{l}\text { Oxalis latifolia Kunth } \\
\text { PHYLLANTHACEAE }\end{array}$ & $\mathrm{E}$ & EX & PI & 3 & 2 \\
\hline $\begin{array}{l}\text { Phyllanthus tenellus Roxb. } \\
\text { PIPERACEAE }\end{array}$ & $\mathrm{E}$ & $\mathrm{N}$ & SI & 0 & 2 \\
\hline $\begin{array}{l}\text { Piper umbellatum } \mathrm{L} \text {. } \\
\text { POACEAE }\end{array}$ & Sub_B & $\mathrm{N}$ & SI & 1 & 1 \\
\hline Digitaria sanguinalis (L.) Scop. & $\mathrm{E}$ & EX & PI & 5 & 8 \\
\hline Echinochloa crusgalli (L.) P.Beauv. & $\mathrm{E}$ & EX & PI & 0 & 1 \\
\hline Eleusine indica (L.) Gaertn. & $\mathrm{E}$ & EX & PI & 1 & 22 \\
\hline $\begin{array}{l}\text { Megathyrsus maximus (Jacq.) B.K.Simon \& S.W.L.Jacobs } \\
\text { PORTULACACEAE }\end{array}$ & $\mathrm{B}$ & EX & PI & 0 & 4 \\
\hline $\begin{array}{l}\text { Portulaca oleracea } \mathrm{L} \text {. } \\
\text { SOLANACEAE }\end{array}$ & $\mathrm{E}$ & EX & PI & 0 & 1 \\
\hline Datura stramonium $\mathrm{L}$. & $\mathrm{B}$ & EX & $\mathrm{SC}$ & 0 & 1 \\
\hline Solanum bonariense $\mathrm{L}$. & $\mathrm{B}$ & $\mathrm{N}$ & $\mathrm{SC}$ & 0 & 1 \\
\hline Solanum americanum Mill. & $\mathrm{E}$ & $\mathrm{N}$ & PI & 0 & 8 \\
\hline $\begin{array}{l}\text { Solanum sisymbriifolium Lam. } \\
\text { TYPHACEAE }\end{array}$ & $\mathrm{B}$ & $\mathrm{N}$ & SC & 1 & 6 \\
\hline $\begin{array}{l}\text { Typha latifolia } \mathrm{L} \text {. } \\
\text { CANNABACEAE }\end{array}$ & $\mathrm{E}$ & $\mathrm{N}$ & SC & 0 & 1 \\
\hline $\begin{array}{l}\text { Trema micrantha (L.) Blume. } \\
\text { URTICACEAE }\end{array}$ & A & $\mathrm{N}$ & PI & 3 & 0 \\
\hline $\begin{array}{l}\text { Cecropia hololeuca Miq. } \\
\text { VERBENACEAE }\end{array}$ & A & $\mathrm{N}$ & PI & 14 & 1 \\
\hline
\end{tabular}

FLORESTA, Curitiba, PR, v. 51, n. 3, p. 760-766, jul/set 2021. 


\begin{tabular}{|c|c|c|c|c|c|}
\hline Lantana camara L. & $\mathrm{B}$ & EX & $\mathrm{PI}$ & 2 & 0 \\
\hline TOTAL & & & & 162 & 1343 \\
\hline
\end{tabular}

In which: $\mathrm{LF}=$ Life form: $\mathrm{T}=$ Tree; $\mathrm{H}=$ Herbaceous; $\mathrm{S}=$ shrubs; $\mathrm{V}=$ Vines/Climbing plants. $\mathrm{SC}=$ Successional category: $\mathrm{PI}=\mathrm{Pioneer} ; \mathrm{IS}=$ Initial secondary; $\mathrm{LS}=$ Late Secondary, and $\mathrm{NC}=$ No Classification. $\mathrm{OR}=$ Origin: $\mathrm{N}=$ Native; $\mathrm{EX}=$ Exotic.

Onde: FV = Forma de vida: A= árvore; $\mathrm{E}=$ herbácea; $\mathrm{B}=$ arbusto; $\mathrm{T}=$ trepadeira, $\mathrm{CS}=$ Categoria Sucessional: $\mathrm{PI}=\mathrm{Pioneira}$; $\mathrm{SI}=\mathrm{Secundaria}$ inicial; $\mathrm{ST}=$ Secundaria tardia e SC = Sem Caracterização; $\mathrm{OR}=$ Origem: N= Nativa; $\mathrm{EX}=$ exótica.

There was a greater number of individuals in the PL compared to PERD. The presence of 24 native species was found in the PERD (75\%) and 23 native species in the PL (59\%). In addition, 8 exotic species were found in the PERD (25\%) and 16 exotic species in the PL (41\%).

In analyzing the PL area, it can be seen that $82.57 \%$ of the individuals found were represented by the $M$. calabura species, an exotic tree species, with a phytogeographic domain in the Amazon, followed by $L$. leucocephala, an exotic species naturalized in Brazil, representing 5.88\% of the total number of individuals found in this environment. There was also a proportion of $2.6 \%$ of individuals of the $S$. orientalis species in PL, thus representing the three species with the highest density of individuals in this area.

It is possible to highlight two species for the PERD area, which presented the largest amounts of germinated seeds in the seed bank, these being C. iria, a native herbaceous species which represented $21.6 \%$ of the total found in this area; and M. calabura, an exotic species which represented $12.3 \%$ of the emerging individuals in the PERD area. L. leucocephala only represented $1.2 \%$ of the individuals found in this environment.

A domain of species with herbaceous growth habit was observed in analyzing the seed bank of both stands (31.2\% in PERD and $61.5 \%$ in PL), which is normal in this type of study, followed by trees in PERD (25\%) and shrubs in the PL area (17.9\%). Next, there was also the presence of $21.8 \%$ sub-shrub species, $18.7 \%$ shrubs and $3.1 \%$ vines in the PERD area, and $10.4 \%$ sub-shrubs, $7.6 \%$ trees and $2.5 \%$ vines in the PL.

The $C$. iria species stood out for the herbaceous domain, which despite being a native species, can behave as an invasive species, proliferating rapidly within natural communities due to disturbances created by changes in the original habitat (NETO and SILVA, 2011), and is found in both evaluated environments. In addition to this species, A. rudis, which is also classified as a weed, occupies a prominent place in view of the negative effects observed in the development, production and quality of the final product of some cultures (BARBOSA and SANTIAGO, 2012); this characteristic can also be observed for I. hederifolia and C. trilobata. In this sense, weed species need to be known and monitored so that any control procedures are implemented more effectively if necessary in the future (MARTINS, 2014).

Only 8 tree species were identified in the evaluated areas, namely: C. hololeuca, C. urucurana, $M$. calabura, P. macropoda, S. campanulata, Tabebuia sp., T. cacao, T. micrantha, all being present in PERD and only 3 present in PL ( $C$. hololeuca, $M$. calabura and $P$. macropoda). Therefore, the presence of a greater diversity of native tree species can be observed in the seed bank of the most conserved environment (PERD), which can guarantee and/or facilitate the process of successional advance of the area.

The Asteraceae family presented the largest domain of species in both evaluated sites, representing $28.2 \%$ in the PL and $28.1 \%$ in the PERD, followed by the Poaceae and Solanaceae families (both with $10.2 \%$ in the PL) and the Fabaceae family in PERD, represented by $9.3 \%$ of the total species found.

\section{DISCUSSION}

According to the results obtained in this study and consolidating the natural trend found in nature, the density of the seed bank varies greatly from one location to another, but tends to be higher in secondary forests or altered areas where the more open canopy enables greater density of pioneer species, whose species have high dispersion and seed production, in addition to remaining viable in the soil seed bank for a longer time due to their dormancy (RODRIGUES et al., 2010; CAPELLESSO et al., 2015). Thus, the largest number of individuals in the PL can be related to the area's characteristics (stand inserted in a region of constant anthropic pressure - urban center), in addition to the greater domain of exotic species, which may be related to urban afforestation actions (i.e. M. calabura), or ease of dispersion, such as L. leucocephala and E. indica.

Although adult individuals of $M$. calabura were not observed in the studied areas, the high density of germinated seeds can be explained by its efficient dispersion by birds and bats and great longevity of the seeds in the soil, which may have favored its presence in the seed banks of both areas (SOARES et al., 2016). Thus, special attention should be paid to this species, since it has rapid growth, early reproductive maturation, a long fruiting period and great attractiveness to avifauna (HOROWITZ et al., 2014), thereby being able to have a high invasive potential and wide dispersion.

However, despite the fact that the PL had a higher density of individuals, they were mostly characterized as weeds, which demonstrates the ecological fragility in this environment and its low resilience, since the soil seed bank demonstrates the tendency future of the environment in facing an eventual environmental disturbance which may occur along the way, as also verified by Guimarães et al. (2014). Thus, as presented by Martins (2007), a soil 
seed bank rich in weed or ruderal species suggests that these species may come to colonize the competing and/or inhibiting native species in the face of a natural or anthropic disturbance, such as the opening of clearings, in turn affecting the sustainability of the ecosystem.

Therefore, through the results found in this study, it is observed that individuals of the species M. calabura were found even in the most preserved area (PERD), thus demonstrating the invasion of the area with this exotic species, in addition to other exotic species with invasion potential, such as L. leucocephala, S. campanulata, O. corniculata, O. latifolia, D. sanguinalis, E. indica and L. camara, which demonstrates the fragility of this environment and the need for actions to control the spread of these species in the area.

The presence of the L. leucocephala species in both environments (but in greater quantity in the PL), also consolidates its high invasive potential, since it is a species of rapid occupation and dissemination, with great potential to become monodominant in the environment and thus inhibit or harm the establishment of species essential to ecological succession. It is worth mentioning that L. leucocephala's dispersion syndrome is by gravity (barochory), and the seeds can be dispersed more than 15 meters away (DALMOLIN et al., 2011), which in terms of dispersion restricts it when compared with $M$. calabura.

In addition, due to the fact that the $M$. calabura species produces fruits several times a year, it is possible that both seeds stored in the soil, as well as seeds recently arrived from nearby matrices, were collected via ornithochoric dispersion. L. leucocephala tends to disperse in the winter in the months of June to August in this region, and so the seeds germinated in the soil samples must be composing the persistent seed bank.

It can generally be seen that the seed banks were mainly composed of herbaceous species, which is common in seed bank studies, especially in environments that have suffered some type of disturbance (CALEGARI et al., 2013). This can be verified through the domain of the Asteraceae family in both evaluated sites, since the species of this group generally have a generalist biology and high capacity for wind dispersal.

Furthermore, due to their high capacity for dispersion and adaptation to different environments (rusticity), some species have the potential to inhibit the development of other plants (SOUSA et al., 2012), which, added to the fact that they remain viable in the seed bank for a longer period than the other species (not pioneer), they guarantee their survival and dissemination in different environments and conditions.

\section{CONCLUSION}

- Both evaluated environments are in undergoing an ecological succession process, however, interventions in the process are necessary in order to assist in controlling exotic species and to increase the diversity of native species, especially in the PL area.

- The two areas are under strong environmental pressure with the presence of exotic species with high aggressiveness and invasive potential, especially the M. calabura and L. leucocephala species, which must be monitored and managed in both analyzed environments in order to control their dispersal.

- The presence of some important species in the succession and in the recovery of degraded areas such as $C$. hololeuca, C. urucurana and T. micrantha reflects the resilience of the PERD area to regenerate itself in the face of disturbances.

- In addition to controlling exotic invaders in the PL area, it is recommended to enrich it by planting native species of diversity in order to accelerate the forest restoration process and make it more effective.

\section{REFERENCES}

APG IV - THE ANGIOSPERM PHYLOGENY GROUP. An update of the Angiosperm Phylogeny Group classification for the orders and families of flowering plants: Botanical Journal of the Linnean Society, London, v.181, n.1, p.1-20, 2016.

BALESTRIN, D.; MARTINS, S. V.; FONSECA, W.; COSIMO, L. H. E. Banco de sementes do solo e sua relação com o dossel em uma área minerada. Revista Árvore, Viçosa, v.43, n.4, p. e430403, 2019.

BARBOSA, F. R.; SANTIAGO, C. M. Informações técnicas para a cultura do arroz irrigado no Mato Grosso do Sul: 2012-2014. Embrapa Arroz e Feijão, Santo Antônio de Goiás, 2013. 160p.

CAlEGARI, L.; MARTINS, S. V.; CAMPOS, L. C.; SILVA, E.; GLERIANI, J. M. Avaliação do banco de sementes do solo para fins de restauração florestal em Carandaí, MG. Revista Árvore, Viçosa, v.37, n.5, p.871$880,2013$.

CAPELLESSO, E. S.; SANTOLIN, S. F.; ZANIN, E. M. Banco e chuva de sementes em área de transição florestal no sul do Brasil. Revista Árvore, Viçosa, v.39, n.5, p.821-829, 2015. 
CORREIA, G. G. D. S.; MARTINS, S. V. Banco de sementes do solo de floresta restaurada, Reserva Natural Vale, ES. Floresta e Ambiente, Seropédica, v.22, n.1, p.79-87, 2015.

DALMOLIN, M. F. S.; MALAVASI, U. C.; MATOS MALAVASI, M. Dispersão e germinação de sementes de Leucaena leucocephala (Lam.) de Wit na Região Oeste do Paraná. Semina: Ciências Agrárias, Londrina, v.32, n.1, p.355-361, 2011.

GANDOLFI, S.; LEITÃO FILHO, H. F.; BEZERRA, C. L. F. Levantamento florístico e caráter sucessional das espécies arbustivo-arbóreas de uma floresta semidecídua no município de Guarulhos, SP. Revista Brasileira de Biologia, São Carlos, v. 55, n.4, p.753-767, 1995.

GUIMARÃES, S.; MARTINS, S. V.; NERI, A. V.; GLERIANI, J. M.; SILVA, K. A. Banco de sementes de áreas em restauração florestal em Aimorés, MG. Pesquisa Florestal Brasileira, Colombo, v.34, n.80, p.357-368, 2014.

HOROWITZ, C.; MARTINS, C. R.; WALTER, B. M. T. Flora exótica no Parque Nacional de Brasília: levantamento e classificação das espécies. Biodiversidade brasileira, Brasilia, n.2, p.50-73, 2014.

IEF-MG (Instituto Estadual de Florestas). Parque Estadual do Rio Doce. Belo Horizonte-MG. Disponível em: http://www.ief.mg.gov.br/images/stories/plano_manejo_perd/resumo.pdf Acesso: 06/04/2020.

KÖPPEN, W. Climatologia: com um estúdio de los climas de la tierra. México: Fundo de Cultura Econômica, $1948,478 \mathrm{p}$.

LIMA, M. T.; TONELlO, K. C.; LEITE, E. C.; FRANCO, F. S.; CORRÊA, C. J. P. Dinâmica da recuperação ambiental de pilhas de estéril em mineração de calcário por regeneração natural. Engenharia Sanitaria e Ambiental, Rio de Janeiro, v.25, n.1, p.11-19, 2020.

MARTINI, A.M.Z.; SANTOS, F.A.M. Effects of distinct types of disturbance on seed rain in the Atlantic forest of NE Brazil. Plant Ecology, Dordrecht, v.190, p.81-95, 2007.

MARTINS, S.V. Recuperação de áreas degradadas: ações em áreas de preservação permamente, voçorocas, taludes rodoviários e de mineração. Viçosa: Aprenda Fácil Editora, 2009, 270p.

MARTINS, S.V. Recuperação de matas ciliares. 3ª Edição. Viçosa: Editora Centro de Produções Técnicas, 2014, 220p.

MARTINS, S.V.; COLLETTI JUNIOR, R.; RODRIGUES, R.R.; GANDOLFI, S. Colonization of gaps produced by death of bamboo clumps in a semideciduous mesophytic forest in southeastern Brazil. Plant Ecology, Dordrecht, v.172, n.1, p.121-131, 2004.

MARTINS S.V. Recuperação de áreas degradadas: ações em áreas de preservação permanente, voçorocas, taludes rodoviários e de mineração. $3^{\mathrm{a}}$ ed. Viçosa: Aprenda Fácil, 2013, 264p.

NETO, R. M. R.; SILVA, D. F. Banco de sementes de um remanescente florestal e duas áreas de pastagem de diferentes idades, em Alta Floresta/MT. Revista Brasileira de Ciências Agrárias, Pernambuco, v.6, n.1, p.113120,2011

NETO, M. A.; MARTINS, S. V.; SILVA, K. D. A.; LOPES, A. T.; DEMOLINARI, R. D. A. Banco de sementes em mina de bauxita restaurada no Sudeste do Brasil. Floresta e Ambiente, Seropédica, v.24, p. e00125414, 2017.

OLIVEIRA, T. J. F.; BARROSO, D. G.; DE ANDRADE, A. G.; FREITAS, I. L. J.; AMIM, R. T. Banco de sementes do solo para uso na recuperação de matas ciliares degradadas na região noroeste fluminense. Ciência Florestal, Seropédica, v.28, n.1, p.206-217, 2018.

RODRIGUES, B. D.; MARTINS, S. V.; LEITE, H. G. Avaliação do potencial da transposição da serapilheira e do banco de sementes do solo para restauração florestal em áreas degradadas. Revista Árvore, Viçosa, v.34, n.1, p.65-73, 2010.

SILVA, L.V.C.; VIANA P. L.; MOTA, N. F. O. Diagnóstico da Cobertura Vegetal. Unidade de Conservação e Zona de Amortecimento, Marliéria, 2001, 104 p.

SOARES, A. A. V.; BOTELHO, S. A.; DAVIDE, A. C.; FARIA, J. M. R. Influência da composição de grupos ecológicos, espaçamento e arranjo de plantio na recuperação de matas ciliares em margem de reservatório. Ciência Florestal, Santa Maria, v.26, n.4, p.1107-1118, 2016.

SOUSA, V. S.; MACHADO FILHO, H. O.; ANDRADE, T. M. Similaridade de vegetação ruderal entre regiões do Brasil. Revista Geonorte, Manaus, v.3, n.4, p.274-283, 2012. 